\title{
Production of components with plaster residue and sodium citrate: physical, mechanical, rheological analysis
}

\author{
Produção de componentes com resíduo de gesso e citrato \\ de sódio: análise física, mecânica, reológica
}

\section{Deborah Grasielly Cipriano da Silva Clóvis Veloso de Santana Yeda Vieira Póvoas}

\begin{abstract}
7 he construction industry, a major influencer in Brazil’s economic and social development, is responsible for a large consumption of raw materials and waste production. In particular, plaster presents significant growth, especially in the Northeast, due to the region of Araripe, great producer of this construction material. Considering the serious problems caused by the incorrect disposal of plaster in nature, there is the challenge of its recycling process. This research aimed to analyze several percentages of plaster residues to be added to the plaster paste, with and without retarder additive (sodium citrate), in terms of physical, mechanical, and rheological properties, focusing at the production of components. For that, the residue underwent physic-chemical recycling process to be replaced by plaster or by mass, in the percentages of $25 \%, 50 \%, 75 \%$ and $100 \%$. The study of the performance of the material was done through the tests of granulometry, unit mass, mini-slump method, calorimetry, squeeze-flow method, compressive strength, and surface hardness. The results showed that the recycled plaster (RP) did not excessively damage the studied properties, and it was permissible to substitute up to $50 \%$ of $\mathrm{RP}$ in the production of the paste for components, following the recommendations of the recycling process and water/plaster ratio.

Keywords: Plaster. Residue. Sodium citrate. Rheology.

\section{Resumo}

A indústria da construção civil, grande influenciadora no desenvolvimento econômico e social do país, é responsável por um grande consumo de matéria prima e produção de resíduos. O gesso, em especial, apresenta crescimento expressivo, sobretudo na região Nordeste, devido ao Pólo Gesseiro do Araripe.

${ }^{1}$ Deborah Grasielly Cipriano da Silva ${ }^{1}$ Universidade de Pernambuco Recife - PE - Brasil

${ }^{2}$ Clóvis Veloso de Santana 2Universidade de Pernambuco Recife - PE - Brasil

${ }^{3}$ Yeda Vieira Póvoas ${ }^{3}$ Universidade de Pernambuco Recife - PE - Brasil

Recebido em 15/12/17

Aceito em 13/07/18

Considerando os graves problemas de seu descarte incorreto à natureza, surge o desafio de sua reciclagem. O objetivo desta pesquisa é analisar diversos percentuais de resíduo de gesso a serem adicionados à pasta de gesso, com e sem aditivo retardador (citrato de sódio), quanto a propriedades físicas, mecânicas e reológicas, visando à produção de componentes. Para tanto, o resíduo passou por processo fisico-químico de reciclagem para ser substituído pelo gesso, em massa, nos percentuais de 25\%, 50\%, 75\% e 100\%. O estudo do desempenho do material foi feito através dos ensaios de granulometria, massa unitária, método do minislump, calorimetria, método squeeze-flow, resistência à compressão e dureza superficial. Os resultados mostraram que o gesso reciclado (GR) não prejudica excessivamente as propriedades estudadas, sendo admissível a substituição de até 50\% do GR na produção da pasta para confecção de componentes, respeitando-se as recomendações do processo de reciclagem e relação água/gesso.

Palavras-chave: Gesso. Resíduo. Citrato de sódio. Reologia.
\end{abstract}




\section{Introduction}

Known as one of the most important activities for Brazil's economic and social development, civil construction is responsible for the consumption of $40 \%$ to $75 \%$ of all raw material produced on the planet (AGOPYAN, 2013).

Together with this large consumption of raw material, the growing production of waste is alarming. According to the United Nations Environment Program - PNUMA (PROGRAMA..., 2011), consuming more than a third of the planet's resources, the construction industry generates approximately $40 \%$ of the world's solid waste.

The problem of the production of solid waste arouses a great concern. In developed countries of Europe, the waste from the construction industry has high rates of reuse and recovery. However, in other countries, also in the European Union, problems of bad destination can be noticed, similar to Brazil (MÁLIA; BRITO; BRAVO, 2011).

In previous studies such as Poon (1997), Wang et al. (2004), Cochran et al. (2007) and Lage et al. (2010), Construction and Demolition Wastes (CDW), despite their large volume, were not seen as so important to the industry because they did not present such a large environmental threat as hazardous waste. However, with the survey of possible environmental impacts and the recycling potential of CDW components, more attention has been paid to this waste stream (BERGSDAL; BOHNE; BRATTEBØ, 2007; COCHRAN et al., 2007).

Brazil, the largest gypsum producer in South America and the 13th largest in the world, has its highest concentration in the state of Pernambuco (BRASIL, 2015). The gypsum from Araripina, in Pernambuco, has the best quality in the world, presenting purity contents of 80 to $95 \%$ (BALTAR; BASTOS; LUZ, 2005).

Due to the high purity and abundance of raw material, combined with the fast execution, good performance and low cost of plaster (the main product of gypsum), the plaster industry has been gaining ground in Brazil and in the world.

However, the fact that gypsum has a low cost and can be easily found brings certain devaluation of the raw material and the lack of concern on the part of the industry to reduce the waste or reuse the waste generated. This is easily seen by the large volume of waste produced by the plaster industry.

Plaster residue is usually generated in four situations:

(a) extraction and preparation of the raw material; (b) the plaster production process;

(c) component processing; and

(d) application of the material and components during construction (PINHEIRO, 2011).

According to Araújo (2002), the percentage of waste/residues produced by the industry in the plaster production stage is around $10 \%$ to $15 \%$ of the production of beta plaster, and $25 \%$ of the production of alpha plaster. Considering that, according to Agronomic Institute of Pernambuco IPA (INSTITUTO..., 2014), the average production of the local calcination industries is around 3.000t of plaster per month; it is assumed that the average production of 300 to 450 tons of plaster waste produced monthly in factories is alarming.

Plaster residue, according to CONAMA Resolution $n^{0}$. 431, dated May 24, 2011 (CONSELHO..., 2011), is classified as a recyclable waste. However, it is easily disposed in an inappropriate way without any treatment.

One of the big villains in construction, plaster residue is contaminating soil and water, and has consequences for human health. When placed in an irregular form, plaster residue enables the generation of hydrogen sulfide gas $\left(\mathrm{H}_{2} \mathrm{~S}\right)$, a substance that can cause serious poisoning effects such as paralysis of the nervous system and asphyxiation, besides being inflammable, causing irritation to the eyes and, depending on the concentration, can be lethal (PINHEIRO, 2011; CARTAXO; FREITAS; ZANTA, 2013).

Within this context, this work provides for the recycling of plaster waste produced in industry, suggesting the replacement of plaster through the residue in order to produce components.

In the manufacture of plaster products, depending on the consistency of the pastes, in order to reach a good workability/fluidity, additives are sometimes used. Due to its fast hardening, the most commonly used additives are the retarders, which increase the time available for paste handling, and the superplasticizers, which provide fluidity/plasticity for molding (DOMINGUEZ; SANTOS, 2002; MILLÁN, 1997; ALVES et al., 2012; ANDRADE et al., 2016).

Previous work such as Ribeiro (2006), Pinheiro (2011) and Pinto (2014) found that plaster, when subjected to the recycling process, has a reduction in setting time, so this work aimed at improving the most damaged property of recycled plaster: the setting time. 
Based on the results above, this study made use of the addition of sodium citrate to mixtures with recycled plaster in order to improve the properties of pastes.

\section{Materials and methods}

The study was subdivided into two phases: the first phase, concerning the production of recycled plaster through the physic-chemical treatment of the plaster waste collected; and the second one, on the performance analysis of pastes with the addition of recycled plaster and the sodium citrate additive plaster retarder.

\section{Phase 1: production of recycled plaster}

For the study, the residue of a plaster factory was used. The recycling process consisted of three steps: waste cleaning, milling and calcination. After milling, the residue was calcined in a hot belly-type oven over a period of 1 hour at a temperature of approximately $145{ }^{\circ} \mathrm{C}$. Then, the residue - now "recycled plaster" was collected and packed in bags that were subsequently covered by paper film so that it would not absorb humidity from the air.

\section{Phase 2: performance analysis of the recycled plaster}

For the performance analysis of the recycled plaster (RP), the substitution of 25\%, 50\%, 75\% and 100\% of plaster by RP in the beta plaster paste (BP) was studied, using BP 100\% paste - without addition of $\mathrm{RP}$. Then, the same mixtures were analyzed with the addition of $0.06 \%$ sodium citrate.

The characterization of the BP and RP materials was performed by analyzing the physical properties of the powder according to NBR 12127 (ABNT, 2017a) in the granulometry and unit mass tests.
Subsequently, the consistency of the mixtures was determined through the mini-slump, which followed Munhoz's methodology (2008). The test equipment consisted of a common glass plate, in the dimensions $(65 \times 65 \times 7) \mathrm{mm}$, with a graphite paper fixed on its underside and a frustoconical PVC mold, with a base of $4 \mathrm{~cm}$ and a top of $2 \mathrm{~cm}$ of diameter, having a height of $6 \mathrm{~cm}$ (Figure 1).

The homogenization process was as follows:

(a) dusting of $\mathrm{BP} / \mathrm{RP}$ mixtures on the water for 30 seconds;

(b) waiting for 1 minute to dissolve the powder;

(c) mixing for 30 seconds.

After this process, the material was transferred to the mold previously centered on the millimeter paper markings. The mold was withdrawn slowly, vertically, resulting in the flow of the mixture onto the glass base. Finally, the diameter formed was read. The mean of two readings indicated the final scattering of the sample.

In the definition of the water/plaster ratio (w/p) the scattering of approximately $75 \mathrm{~mm}$ was adopted, considering that according to Munhoz (2008) and Pinheiro (2011) this is the typical spreading adopted for plaster pastes intended for the production of components for civil construction.

After defining the consistency, the hydration kinetics of the mixtures was analyzed through the hydration heat curves. The instruments used were a pseudo-adiabatic calorimeter similar to that used by Antunes (1999), Pinheiro (2011), Andrade et al. (2014) and Silva (2017), consisting of an insulating vessel; a sample placement vessel; and, for measurement of temperature variation, a K-type thermocouple (Cromel-Alumel) with a digital thermometer with an accuracy of $0.1^{\circ} \mathrm{C}$ to obtain elevation of temperature over time (Figure 2).

Figure 1 - Equipment used to perform the mini-slump

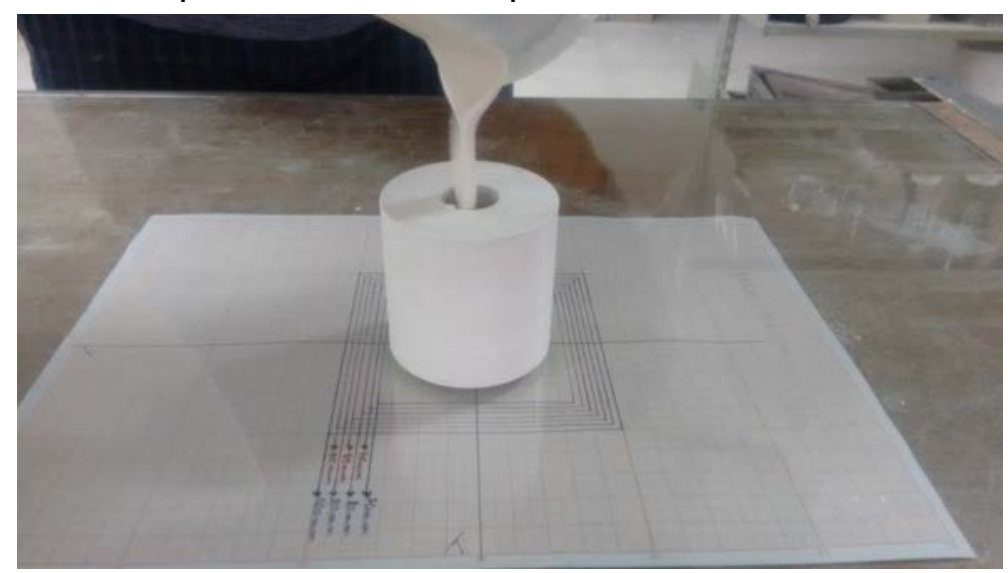


Figure 2 - Pseudo-adiabatic calorimeter scheme

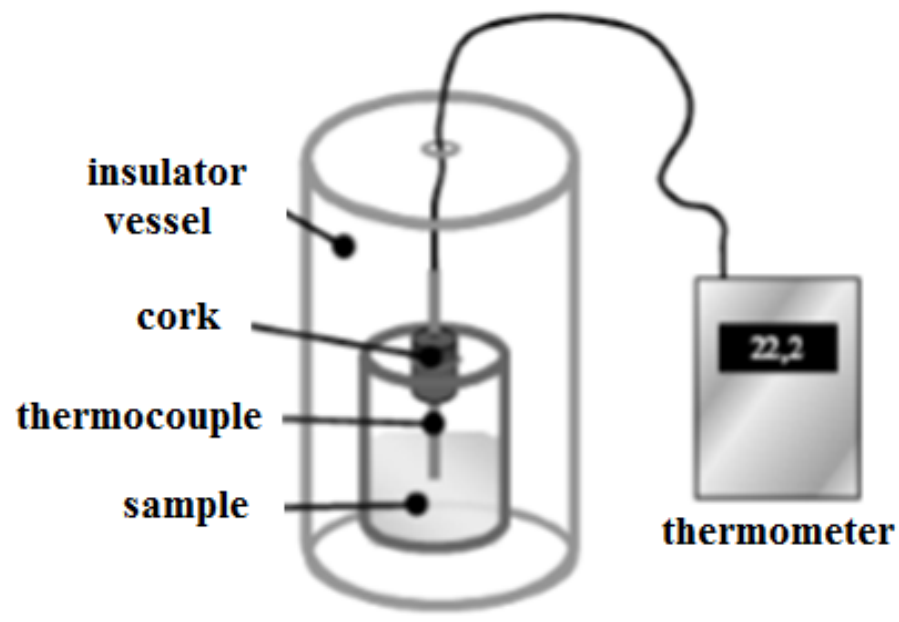

Source: Antunes (1999).

Considering that, according to Andrade et al. (2014), the start time of setting is set at the instant when the temperature rise rate exceeds $0.1^{\circ} \mathrm{C} / \mathrm{min}$ and the end time of setting is determined when the exothermic reaction reaches the maximum temperature, this study also made mention of the calorimeter for the definition of the beginning and end times of setting.

The rheological characterization of the mixtures was done by the squeeze-flow method. The technique is based on measuring the stress required for the uniaxial compression of a cylindrical sample of the material between two parallel plates and has been performed on test universal machine equipment.

For this analysis, 4 samples of $100 \mathrm{~mm}$ diameter per $10 \mathrm{~mm}$ height of each mixture were molded according to NBR 15839 (ABNT, 2010), each sample being tested at $5,10,15$ and 20 minutes (time measured from the contact of the plaster with the water). From the tension applied by a piston of $50 \mathrm{~mm}$ diameter, at a constant speed of $0.1 \mathrm{~mm} / \mathrm{s}$, in a restricted sample, it was possible to verify the ratio of the applied load with the displacement suffered.

After the analysis of the pastes in the fresh state, the mechanical properties of the mixtures were studied. For this, the tests of compressive strength and surface hardness were carried out according to NBR 12129 (ABNT, 2017b).

\section{Results and discussions}

\section{Physical properties of the powder}

The physical properties results of the beta plaster (BP) and recycled plaster (RP) powders are shown in Figure 3 and in Table 1.
According to the granulometric curves obtained, using the sieve openings of 840, 420, 210 and 105 $\mathrm{mm}$, both (BP) and (RP) had continuous grading.

The comminution process carried out on the RP resulted in the formation of a material thicker than BP. Therefore, with a FM larger. According to the characterization, both the beta plaster (BP) and recycled plaster (RP) were classified as plaster for casting with bulk density $(\mathrm{BD}) \geq 600.00 \mathrm{~g} / \mathrm{cm}^{3}$.

\section{Physical properties of the paste}

The consistency of each mixture (with and without the addition of sodium citrate) was defined by the mini-slump test. Table 2 shows the water/plaster ratios defined based on the scattering of the mixtures.

The use of the scattering criteria to define $\mathrm{w} / \mathrm{p}$ ratio was due to the knowledge that the addition of recycled plaster to the paste causes a reduction in the fluidity. Therefore, a w/p ratio was sought that conferred to the mixture a consistency adequate to the use, independent of its constitution (addition of $\mathrm{RP}$ and/or additive).

The definition of different w/p ratios to the pastes allowed a fair comparison between the mixtures, since the fast setting pastes by the addition of the RP were compensated with the addition of water while the pastes with the additive had their w/p ratio reduced.

It is believed that the addition of water to the mixture established a loss in its mechanical properties. However, taking into account the proposed recycling of waste, the study focused only on ensuring that this loss does not compromise its use. 
As for the setting time analysis, Table 3 shows the start and end times of setting for the mixtures (with and without sodium citrate).

Mixtures with addition of RP and without sodium citrate showed a useful time similar to the reference mixture, conferring suitability for use. As for the setting times, the feasibility of adding $25 \%$, $50 \%$, $75 \%$ and $100 \%$ RP to the plaster paste was verified, since the setting end remained stable.

\section{Figure 3 - BP and RP granulometric curves}

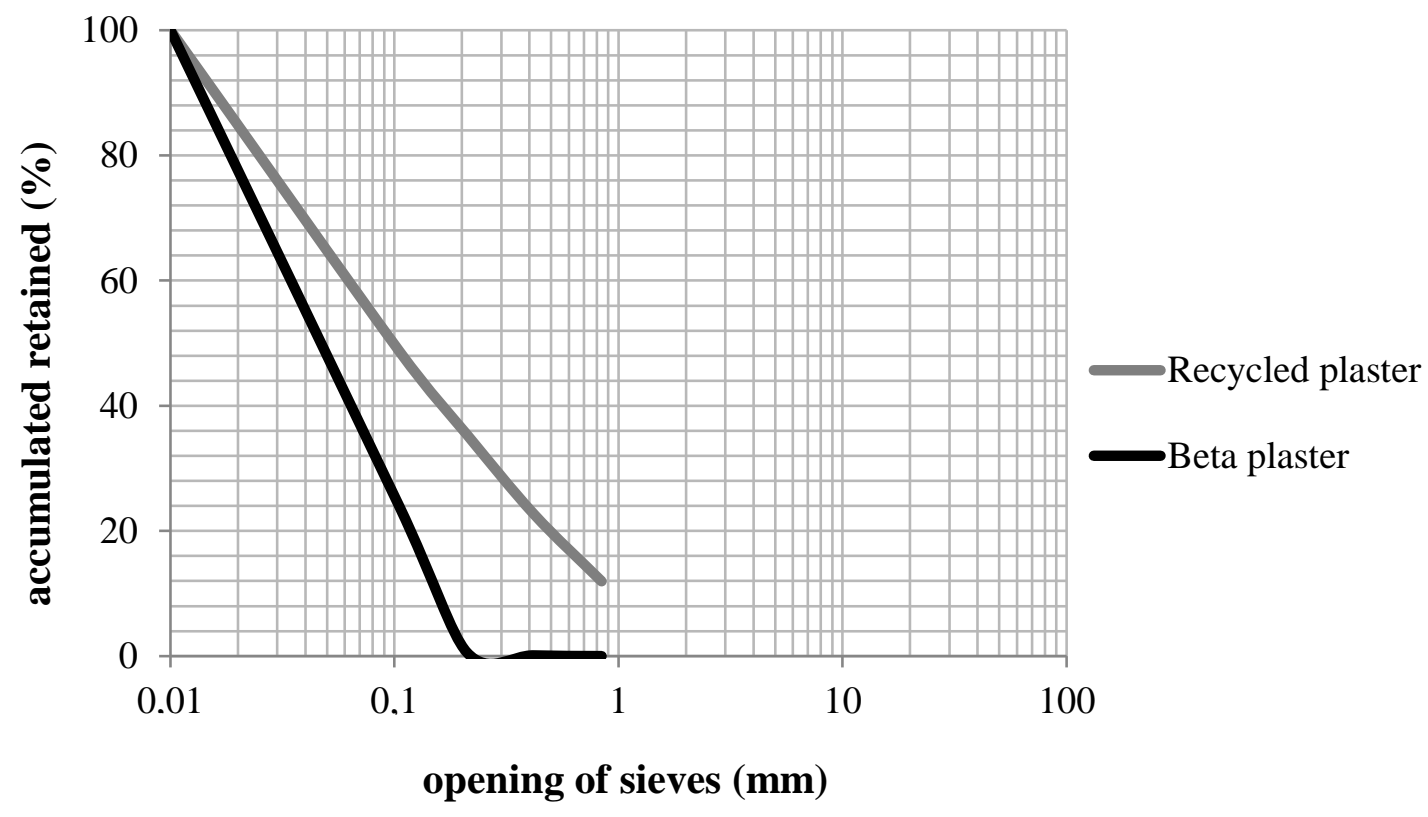

Table 1 - Results of physical properties of BP and RP

\begin{tabular}{c|c|c}
\hline \multirow{2}{*}{ Material } & \multicolumn{2}{|c}{ Properties } \\
\cline { 2 - 3 } & Fineness modulus (FM) & Bulk density (BD) $\mathbf{( g / \mathbf { c m } ^ { 3 } )}$ \\
\hline RP & 1.19 & 659.5 \\
BP & 0.25 & 645.1 \\
\hline
\end{tabular}

Table 2 - Definition of the $\mathbf{w} / \mathbf{p}$ ratio through the mini-slump

\begin{tabular}{c|c|c|c|c}
\hline \multirow{2}{*}{ Description } & \multicolumn{2}{|c|}{ Without sodium citrate } & \multicolumn{2}{c}{ With sodium citrate } \\
\cline { 2 - 5 } & w/p & Scattering (mm) & w/p & Scattering (mm) \\
\hline 0\% (RP) - Reference & 0.62 & 76 & 0.56 & 76 \\
$25 \%(\mathrm{RP})$ & 0.63 & 76 & 0.58 & 76 \\
$50 \%(\mathrm{RP})$ & 0.66 & 74 & 0.58 & 75 \\
$75 \%(\mathrm{RP})$ & 0.69 & 76 & 0.59 & 75 \\
$100 \%(\mathrm{RP})$ & 0.70 & 76 & 0.60 & 74 \\
\hline
\end{tabular}

Table 3 - Start and end times of setting for the mixtures

\begin{tabular}{c|c|c|c|c|c|c}
\hline \multirow{2}{*}{ Description } & \multicolumn{3}{|c|}{ Without sodium citrate } & \multicolumn{3}{c}{ With sodium citrate } \\
\cline { 2 - 7 } & $\begin{array}{c}\text { Setting } \\
\text { Start } \\
\text { (min) }\end{array}$ & $\begin{array}{c}\text { Setting } \\
\text { End } \\
\text { (min) }\end{array}$ & $\begin{array}{c}\text { Service } \\
\text { Time } \\
\text { (min) }\end{array}$ & $\begin{array}{c}\text { Setting } \\
\text { Start } \\
\text { (min) }\end{array}$ & $\begin{array}{c}\text { Setting } \\
\text { End } \\
\text { (min) }\end{array}$ & $\begin{array}{c}\text { Service } \\
\text { Time } \\
\text { (min) }\end{array}$ \\
\hline $0 \%$ (RP) - Reference & 7 & 32 & 25 & 10 & 99 & 89 \\
25\% (RP) & 6 & 31 & 25 & 8 & 89 & 81 \\
$50 \%(\mathrm{RP})$ & 4 & 30 & 26 & 8 & 75 & 67 \\
$75 \%(\mathrm{RP})$ & 5 & 31 & 26 & 7 & 65 & 58 \\
$100 \%(\mathrm{RP})$ & 6 & 32 & 26 & 8 & 99 & 91 \\
\hline
\end{tabular}


The mixtures with the setting retarder additive, however, presented an average increase of approximately $61.5 \%$ at the end times of setting of folders; being attested the good operation for the additive with the recycled plaster.

In the reaction kinetics, Figure 4 shows the heat curves of hydration of the mixtures with and without addition of sodium citrate.

According to the curves, as the recycled plaster was added to the mixtures without the additive, there was a decrease in the heat of hydration of the pastes. Supposedly, the increase in water/plaster ratio offset the acceleration of hardening caused by the addition of recycled plaster. This way, no problem was seen related to the use of the pastes with addition of RP.

When sodium citrate was added, the curves showed that increasing the amount of RP to $25 \%, 50 \%$ and $75 \%$ caused a shift of the curves to the left, reducing the induction time and the maximum temperature of the heat of hydration of the pastes in relation to the reference mixture.

The curve with $100 \%$ RP, in contrast, did not follow the trend of the others. This behavior showed that pure mixtures (100\% BP and 100\% RP) reacted better to the additive effect. However, the curve with $100 \%$ RP maintained the tendency to decrease the maximum hydration temperature in relation to the reference mixture.

The temperature peaks of the pastes with the retarder were similar to those of the mixtures without sodium citrate, indicating that the interference of the additive did not occur in the temperature, but in the hydration kinetics. Increasing in approximately 30\% the induction period of the mixtures, the action of the retarder remained clear, allowing a longer service time for the pastes.

Figures 5 and 6 show the rheological behavior of the mixtures with and without addition of sodium citrate, respectively.

The mixtures with RP, without additive (Figure 5) presented curves which, according to the graph, showed a reduction in plasticity of the pastes in relation to the BP paste (continuous line of the graph).

All the mixtures presented a typical behavior, where, over time, a loss in plasticity was observed, demanding an increase of force to continue the deformation - a natural process of hardening the plaster paste.

At 5 minutes all the mixtures presented fluid, not offering initial resistance to their deformation.

At 10 minutes the pastes still showed a certain fluidity and workability, however, requiring an increase in the load to continue the deformation. The pastes with RP, as predicted, because they had more crystallization nuclei, and therefore faster hardening, were more rigid than the reference paste, demanding a greater increase of force to deform.

Figure 4 - Heat curves of hydration of the mixtures with and without additive

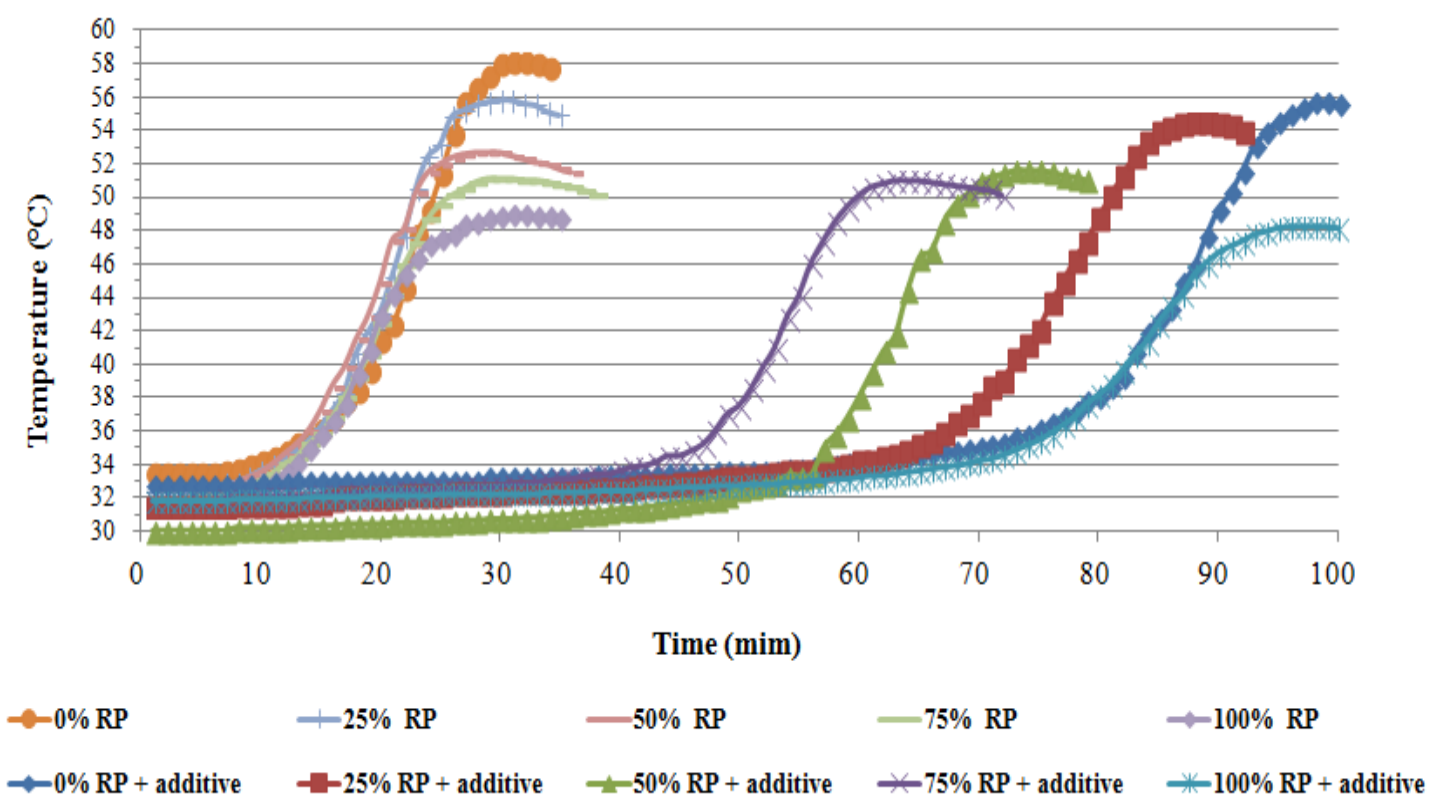


Figure 5 - Rheological behavior of the mixtures: (a) $25 \%$ RP; (b) $50 \%$ RP; (c) $75 \%$ RP; and (d) $100 \%$ RP, relative to BP (solid line)

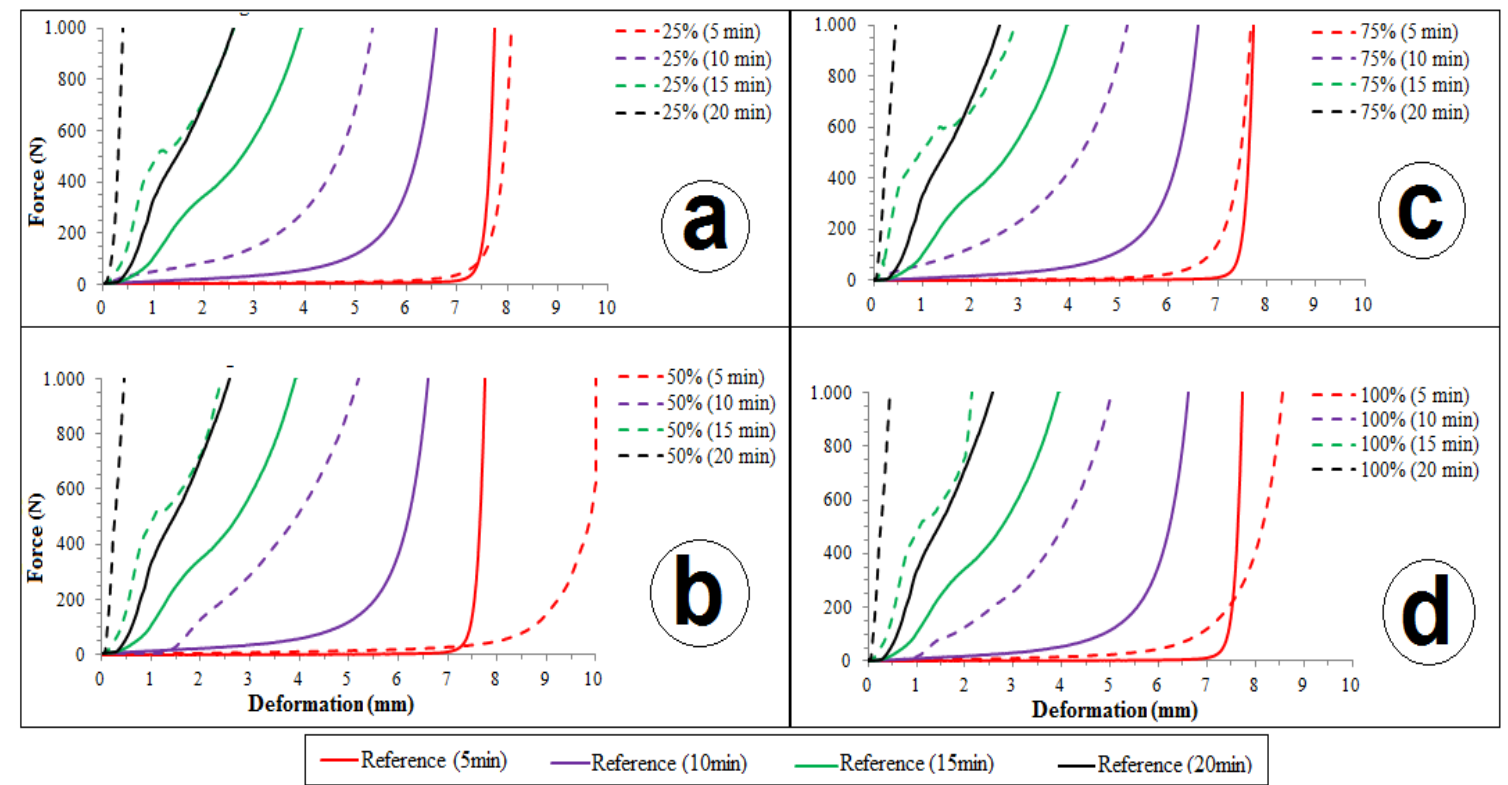

At 15 minutes the pastes with RP showed a need to apply $100 \mathrm{~N}$ of force to deform $1 \mathrm{~mm}$, while the reference paste needed this same force only after deformation of $4 \mathrm{~mm}$. At this stage, the pastes with RP presented little workability, requiring an increase in the load and great effort of the professional for the molding of a prefabricated component.

At 20 minutes, the pastes behaved like a solid, presenting deformation stiffness, especially in the pastes with RP. The deformation was minimal for a load of $1 \mathrm{kN}$.

Regarding the influence of the additive, by analyzing the rheological behavior of the mixtures with RP and sodium citrate (Figure 6), the curves on the graph show an increase in plasticity over time in relation to the $\mathrm{BP}+$ additive, contrary behavior to that without the addition of it.

The reference mixture, under the effect of the additive, had a specific behavior. Initially, at 5 and 10 minutes, it presented easy deformation and good workability. In the following minutes, unlike the same mixture without the additive, instead of presenting greater rigidity, it was more workable. This behavior confirmed what was seen in the results of calorimetry, where the mixture with the retarder had a longer service life compared to the pastes without the additive, which hardened faster.

While the percentage of residue up to $75 \% \mathrm{RP}+$ additive increased, there was a growth in the plasticity of the mixtures. The paste with $100 \%$ RP + additive presented less workability than the one with 75\% RP + additive, but its behavior was better than the other pastes.

At 5 minutes all mixtures with $\mathrm{RP}+$ additive showed a good fluidity for the molding of a prefabricated component and the plasticity remained until the 20 minutes. Only 50\% RP + additive showed a decrease in workability over time.

The addition of sodium citrate allowed the decrease of the $\mathrm{w} / \mathrm{p}$ ratio and improved the workability of all mixtures.

\section{Mechanical properties}

All mixtures with and without addition of sodium citrate were tested for their compressive strength and the comparison of results is shown in Figure 7.

According to the values of compressive strength presented, the mixtures with the retarder presented themselves, in average, of $11.4 \%$ more resistant than the pastes without the additive. As the sodium citrate of $0.06 \%$ by weight in the dry materials allowed the reduction of the $\mathrm{w} / \mathrm{p}$ ratio, the compressive strength improved.

It is worth noting that sodium citrate, as a setting retardant additive, tended to reduce the mechanical properties of the pastes because it modified its crystalline structure (ALVES et al., 2012; PINTO, 2014). However, by allowing the adjustment of the $\mathrm{w} / \mathrm{p}$ ratio still preserving the consistency to the mixtures, the additive allowed to compensate/overcome this loss. 
Figure 6 - Rheological behavior of the mixtures: (a) $25 \%$ RP + additive; (b) $\mathbf{5 0 \%}$ RP + additive; (c) $\mathbf{7 5} \%$ RP + additive; and (d) $100 \%$ RP + additive, relative to BP (solid line)

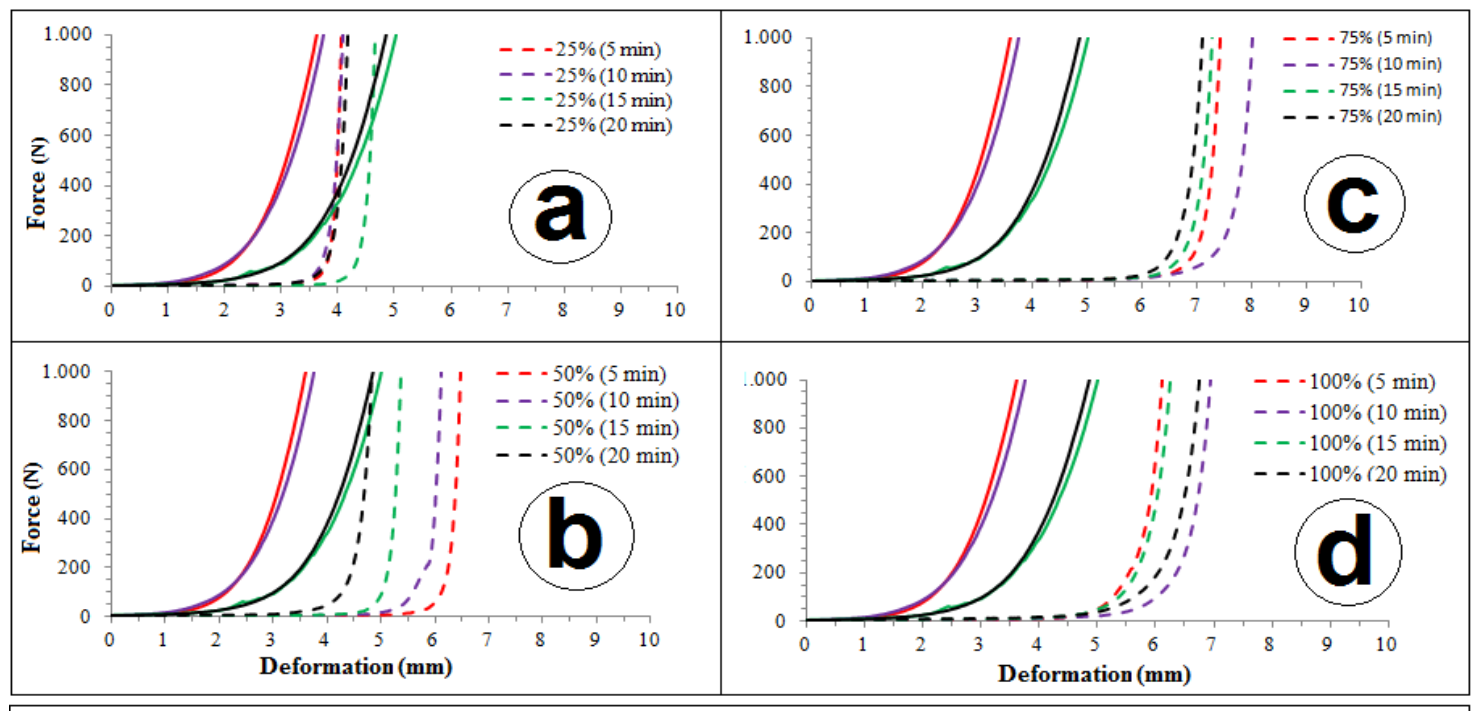

- Reference with additive $(5 \mathrm{~min}) \ldots$ Reference with additive $(10 \mathrm{~min}) \_$Reference with additive $(15 \mathrm{~min}) \_$Reference with additive (20min)

Figure 7 - Influence of sodium citrate on the compressive strength of the mixtures

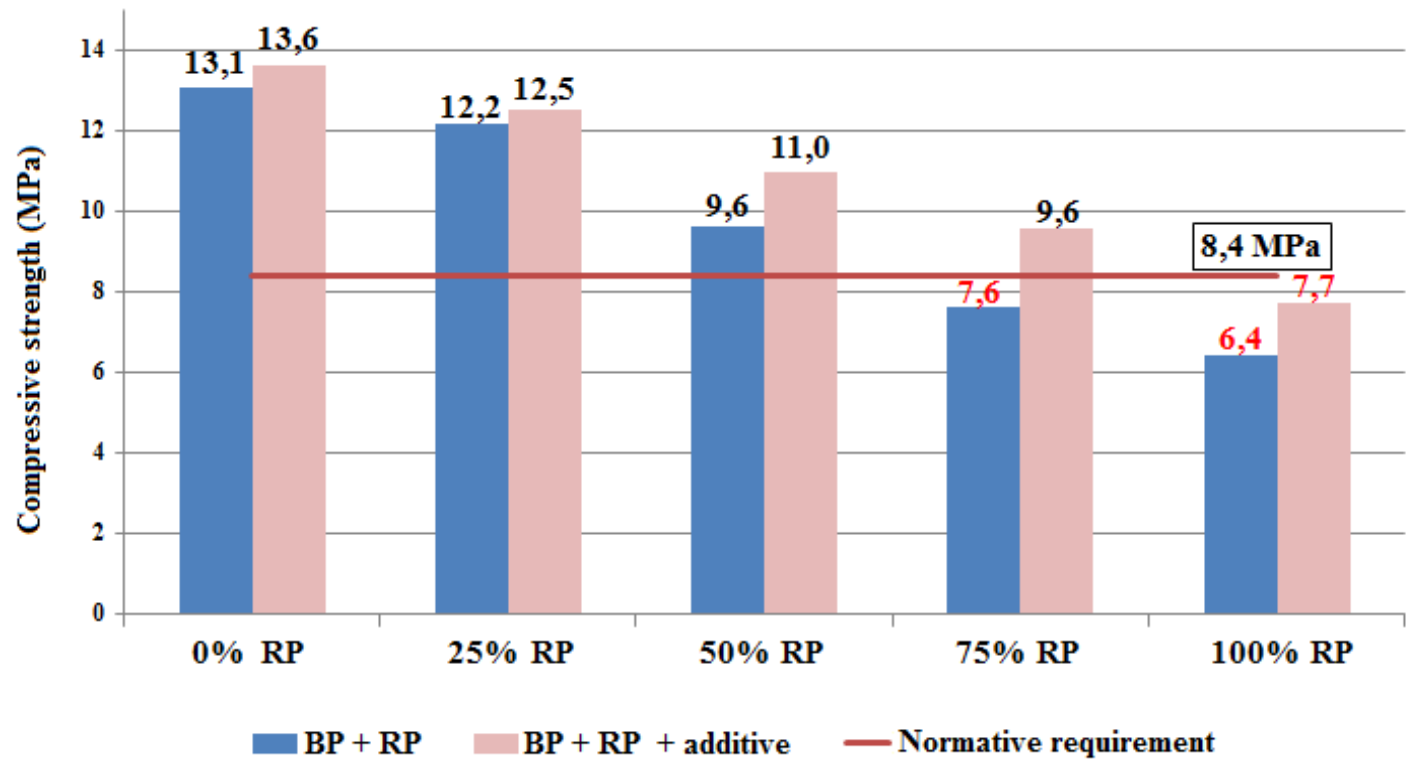

The NBR 13207 (ABNT, 2017c) does not present criteria for the compressive strength of plaster paste, the result being only informative. However, in Figure 7 the value of $8.4 \mathrm{MPa}$ of the previous version was used, of 1994, only as base value.

Regarding surface hardness, Figure 8 shows the average values obtained for the mixtures with and without sodium citrate, in the different ratios of RP, indicating an average difference in the $1.6 \%$ between the mixtures.
Considering that the hardness of the materials represents their ability to resist the risk and wear when subjected to abrasion, and that wear represents the deterioration of the surface of the material, the plaster mixtures with addition of RP and sodium citrate proved to be resistant and adequate to according to ANFOR, CEN/TC 241 (ASSOCIATION..., 2014), where the recommended Shore $C$ hardness value should be greater than 60 u.s.c. 
Figure 8 - Influence of sodium citrate on the surface hardness of the mixtures

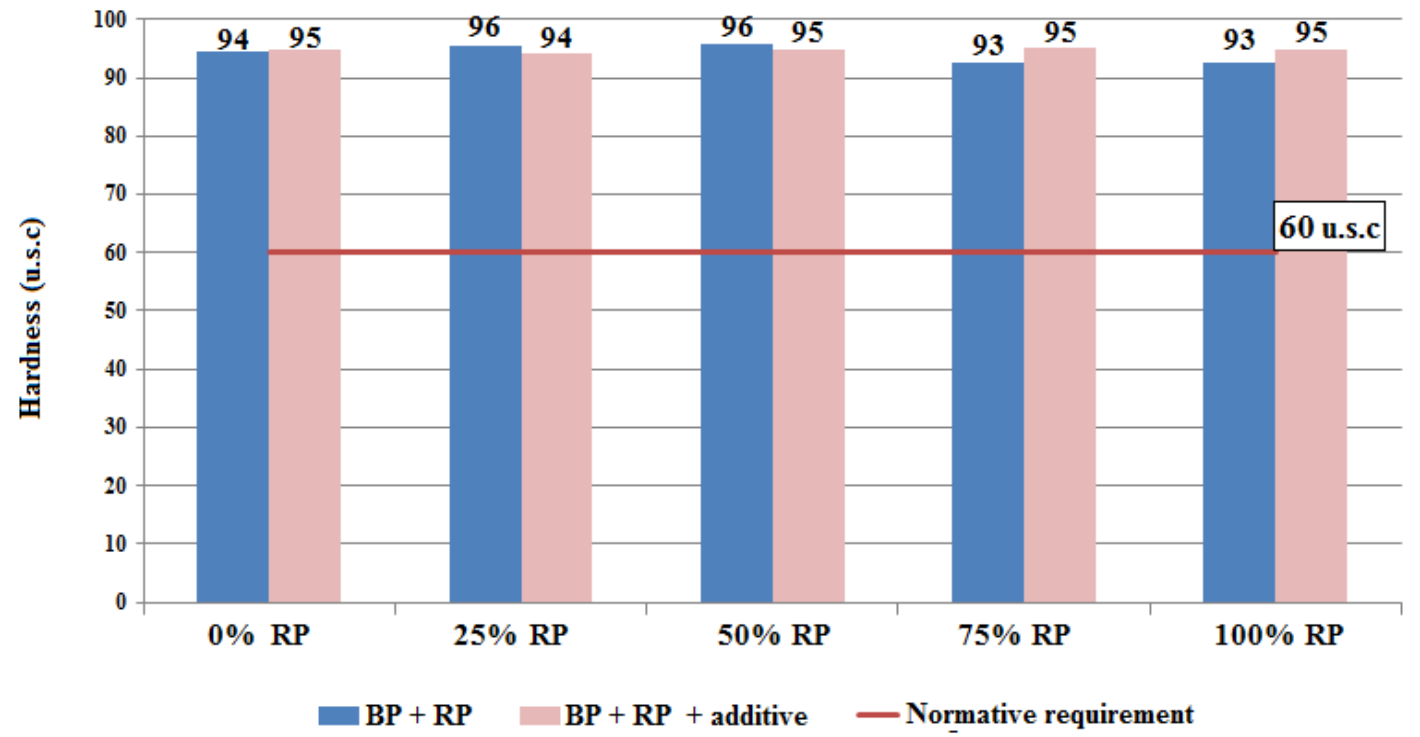

\section{Conclusions}

Although recycled plaster exhibits crystallization cores which accelerate the hardening of the pastes, sodium citrate has been shown to be efficient in prolonging the usefulness of the mixtures. Without the use of this additive, the manual production of prefabricated plaster components should be so fast that it does not prevent the process by generating more industrial waste. The molding proved to be feasible, despite the application of a 100\% RP.

By keeping the consistency suitable for the molding of components, this retarder made it possible to reduce the water/plaster ratio, to leave the paste more workable and to increase the compressive strength of the mixtures.

The possibility of using $100 \%$ RP as an alternative for the reuse of the collected residue in the industry was observed, reducing the deposition of this material in the environment, while presenting the possibility of using a new product with properties similar to beta plaster marketed.

The addition of $0.6 \%$ sodium citrate, by RP mass, was shown as an alternative to obtain a workable mixture for a longer period of time.

Finally, it should be noted that the addition of recycled plaster must take into account the correct treatment of the waste. Any modification in the recycling process, whether in the granulometry or form of the material and calcination time, can change the outcomes.

\section{References}

AGOPYAN, V. Construção Civil Consome Até 75\% da Matéria-Prima do Planeta. Globo Ciência. 2013. Disponível em: <https://goo.gl/wRXEiu>. Acesso em: 27 mar. 2018.

ALVES, B. C. A. et al. Interferência do Citrato de Sódio na Calorimetria da Pasta de Gesso. In: ENCONTRO NACIONAL DE TECNOLOGIA DO AMBIENTE CONSTRUÍDO. 14., Juiz de Fora, 2012. Anais... Juiz de Fora, 2012.

ANDRADE, A. C. et al. Avaliação de Pastas de Gesso Com Aditivo Incorporador de Ar. In: ENCONTRO NACIONAL DE TECNOLOGIA DO AMBIENTE CONSTRUÍDO. 16., São Paulo, 2016. Anais... São Paulo, 2016.

ANDRADE, A. C. et al. Avaliação do Tempo de Pega e do Calor de Hidratação de Pastas de Gesso, Para Revestimento, Com a Incorporação de Resíduos de Gesso In: CONGRESSO BRASILEIRO DE ENGENHARIA E CIÊNCIA DOS MATERIAIS. CBECIMAT, 21. Cuiabá, 2014. Anais... Cuiabá, 2014.

ANTUNES, R. P. N. Estudo da Influência da Cal Hidratada nas Pastas de Gesso. São Paulo, 1999. 134 f. Dissertação (Mestrado em Engenharia Civil) - Escola Politécnica, Universidade Estadual de São Paulo, São Paulo, 1999. 
ARAUJO, F. A. Aplicação da Metodologia de Produção Mais Limpa: estudo em uma empresa do setor da construção civil. 121 f. Florianópolis, 2002. Dissertação (Mestrado em Engenharia de Produção) - Escola de Engenharia, Universidade Federal de Santa Catarina, Florianópolis, 2002.

\section{ASSOCIAÇÃO BRASILEIRA DE NORMAS} TÉCNICAS. NBR 12127: gesso para construção civil: determinação das propriedades físicas do pó. Rio de Janeiro, 2017a.

\section{ASSOCIAÇÃO BRASILEIRA DE NORMAS}

TÉCNICAS. NBR 12129: gesso para construção civil: determinação das propriedades mecânicas, Rio de Janeiro, 2017b.

\section{ASSOCIAÇÃO BRASILEIRA DE NORMAS} TÉCNICAS. NBR 13207: gesso para construção civil: requisitos. Rio de Janeiro, 1994.

\section{ASSOCIAÇÃO BRASILEIRA DE NORMAS} TÉCNICAS. NBR 13207: gesso para construção civil: requisitos Rio de Janeiro, 2017c.

\section{ASSOCIAÇÃO BRASILEIRA DE NORMAS TÉCNICAS. NBR 15839: argamassa de assentamento e revestimento de paredes e tetos: caracterização reológica pelo método squeeze- flow. Rio de janeiro, 2010.}

\section{ASSOCIATION FRANÇAISE DE} NORMALISATION. CEN/TC 241: platres et produits à base de plâtre. Paris, 2014.

BALTAR, C. A. M.; BASTOS, F. F.; LUZ, A. B. Gipsita CT 2005-122. Rio de Janeiro: CETEM Centro de Tecnologia Mineral Ministério da Ciência e Tecnologia, 2005. 23 p. Comunicação Técnica. Disponível em: <https://goo.gl/tp5Z3M>. Acessado em: 27 mar. 2018.

BERGSDAL, H.; BOHNE, R. A.; BRATTEBØ, $\mathrm{H}$. Projection of Construction and Demolition Waste in Norway. Journal of Industrial Ecology, v. 11, n. 3, p. 27-39, 2007.

BRASIL. Departamento Nacional de Produção Mineral. Ministério de Minas e Energia. Balanço Mineral Brasileiro 2015: Gipsita. Brasil: DNPM, 2015. Disponível em: <https://goo.gl/W5PMAS>. Acesso em: 27 mar. 2018.

CARTAXO, G. A. A.; FREITAS, I. M. D. P.; ZANTA, V. M. Análise do Gerenciamento de Resíduos de Gesso no Município de Salvador-BA. In: ENCONTRO NACIONAL DE ENGENHARIA DE PRODUÇÃO, 33., Salvador, 2013. Anais... Bahia, 2013.
COCHRAN, K. et al. Estimation of Regional Building-Related C\&D Debris Generation and Composition: case study for Florida, US. Journal of Waste Management, v. 27, n. 7, p. 921-931, 2007.

\section{CONSELHO NACIONAL DO MEIO}

AMBIENTE. Resolução n. 431, de 24 de maio de 2011, que altera o art. $3^{\circ}$ da Resolução 307, de 5 de julho de 2002, do Conselho Nacional do Meio Ambiente - Conama, estabelecendo nova classificação para o gesso. Diário Oficial da União, Brasília, 25 maio 2011, n. 99, p. 123.

DOMÍNGUEZ, L. V.; SANTOS, A. G. Manual do Gesso. [s.l.: s.n.], 2002.

\section{INSTITUTO AGRONÔMICO DE}

PERNAMBUCO. Simpósio Pólo Gesseiro do Araripe, Potencialidades, Problemas e Soluções. Relatório do evento. Recife, 2014. Disponível em: <https://goo.gl/NDLgLb>. Acesso em: 27 mar. 2018.

LAGE, I. M. et al. Estimation of the Annual Production and Composition of C\&D Debris in Galicia (Spain). Journal of Waste Management, v. 30, n. 4, p. 636-645, 2010.

MÁLIA, M.; BRITO, J.; BRAVO, M. Indicadores de Resíduos de Construção e Demolição Para Construções Residenciais Novas. Ambiente Construído, Porto Alegre, v. 11, n. 3, p. 117-130, jul./set. 2011.

MILLÁN, M. L. Influencia de los Aditivos en las Características Específicas de las Formulaciones Base Yeso. In: GYPSUM FAIR, Olinda, 1997. Proceedings... Olinda: Finep, 1997.

MUNHOZ, F. C. Utilização do Gesso Para Fabricação de Artefatos Alternativos no Contexto de Produção Mais Limpa. 164 f. Bauru, 2008. Dissertação (Mestrado em Engenharia de Produção) - Programa de PósGraduação em Engenharia de Produção, Universidade Estadual Paulista, Bauru, 2008.

PINHEIRO, S. M. M. Gesso Reciclado: avaliação de propriedades para uso em componentes. $352 \mathrm{f}$. Campinas, 2011. Tese (Doutorado)-Faculdade de Engenharia Civil, Departamento de Arquitetura e Construção, Universidade Estadual de Campinas, 2011.

PINTO, M. C. C. Avaliação das Propriedades do Gesso Reciclado Contendo Aditivos. $108 \mathrm{f}$. Campinas, 2014. Dissertação (Mestrado em Engneharia Civil) - Faculdade de Engenharia Civil, Departamento de Arquitetura e Construção, Universidade Estadual de Campinas, 2014. 
POON, C. S. Management and Recycling of Demolition Waste in Hong Kong. Waste Management \& Research, v. 15, p. 561-572, 1997.

\section{PROGRAMA DAS NAÇÕES UNIDAS PARA O} MEIO AMBIENTE. Caminhos Para o Desenvolvimento Sustentável e a Erradicação da Pobreza - Síntese para Tomadores de Decisão. Disponível em: <https://goo.gl/ZWfGRL>. Acesso em: 27 mar. 2018.

\section{RIBEIRO, A. S. Produção de Gesso Reciclado a} Partir de Resíduos Oriundos da Construção Civil Sociais. 86 f. João Pessoa, 2006. Dissertação (Mestrado em Engenharia Civil) - Escola de Engenharia, Universidade Federal da Paraíba, João Pessoa, 2006.
SILVA, A. M. G. Projeção de Argamassa de Gesso: procedimento e análise reológica. 126 f. Recife, 2017. Dissertação (Mestrado em Engenharia Civil) - Escola Politécnica de Pernambuco, Programa de Pós-graduação em Engenharia Civil, Universidade de Pernambuco, Recife, 2017.

WANG, J. Y. et al. A Systems Analysis Tool For Construction and Demolition Wastes Management. Waste Management, v. 24, p. 989-997, 2004.

\section{Acknowledgement}

The present work was carried out with the support of CAPES (Coordination for the Improvement of Higher Education Personnel) and POLI/UPE.

\section{Deborah Grasielly Cipriano da Silva}

Departamento de Engenharia Civil | Universidade de Pernambuco | Rua Benfica, 455, Madalena | Recife - PE - Brasil | CEP 50750-410 | Tel.: (81) 3184-7566 | E-mail: deborahgrasielly@yahoo.com.br

Clóvis Veloso de Santana

Departamento de Engenharia Civil | Universidade de Pernambuco | E-mail: clovisvelososantana@hotmail.com

\section{Yeda Vieira Póvoas}

Departamento de Engenharia Civil | Universidade de Pernambuco | E-mail: yeda. povoas@gmail.com

\section{Revista Ambiente Construído}

Associação Nacional de Tecnologia do Ambiente Construído

Av. Osvaldo Aranha, 99 - 3o andar, Centro

Porto Alegre - RS - Brasil

CEP $90035-190$

Telefone: +55 (51) 3308-4084

Fax: +55 (51) 3308-4054

www. seer. ufrgs. br/ ambienteconstruido

E-mail: ambienteconstruido@ufrgs.br 